ossifications; it bears a pair of long posterior cornua and is movably articulated to the lower surface of the coracoid cartilages. No air-bladder.

\title{
Family Ateleopidx.
}

The genus Ateleopus or Podateles, with four species from the Indo-Pacific, was placed by Günther near the Macruridæ. Boulenger examined the pectoral arch in Ateleopus indicus, and finding that the foramen was intrascapular placed it near the Ophidiidæ among the jugular Acanthopterygians. In a paper read at the Zoological Congress of 1907 I made this genus the type of a separate order, Chondrobrachii, pointing out the improbability that it was related to fishes such as the Blennioids, which have the pelvic bones directly attached to the cleithra above the symphysis.

The evidence of relationship to Aulopus now seems to me so clear that I am disposed to abandon the order Chondrobrachii. Ateleopus scarcely differs more from Aulopus in finstructure than Coilia does from Engraulis, and it is especially noteworthy that the many-jointed simple or bifid pelvic ray is exactly similar to the outer pelvic rays of Aulopus ; it has been wrongly described as two rays bound together; rather it is the two components of one ray which remain distinct and may separate from each other distally. The resemblances and differences in the pectoral arch and pelvis will be seen on comparing figures 3 and 7 . The resemblances in the skull have already been pointed ont, but the skeletal differences, mainly due to degeneration or to a persistence of the conditions usually found in very young fish, seem to justify the recognition of a separate suborder for Aleleopus.

XIV.-A Description of Venus stimpsoni, Gould. By A. J. Jukes-Browne, B.A., F.R.S., M.M.S.

[Plate IV.]

The shell now described and figured (Plate IV.) was first made known and briefly described by A. G. Gould in 1861 * and $1862 \dagger$, but was not figured by him, nor has any sub. sequent writer published a figure of it, probably because very

* Boston Soc. Nat. Hist. vol. viii. (1861).

† 'Otia Conchologica,' p. 169 (Boston, 1862). 


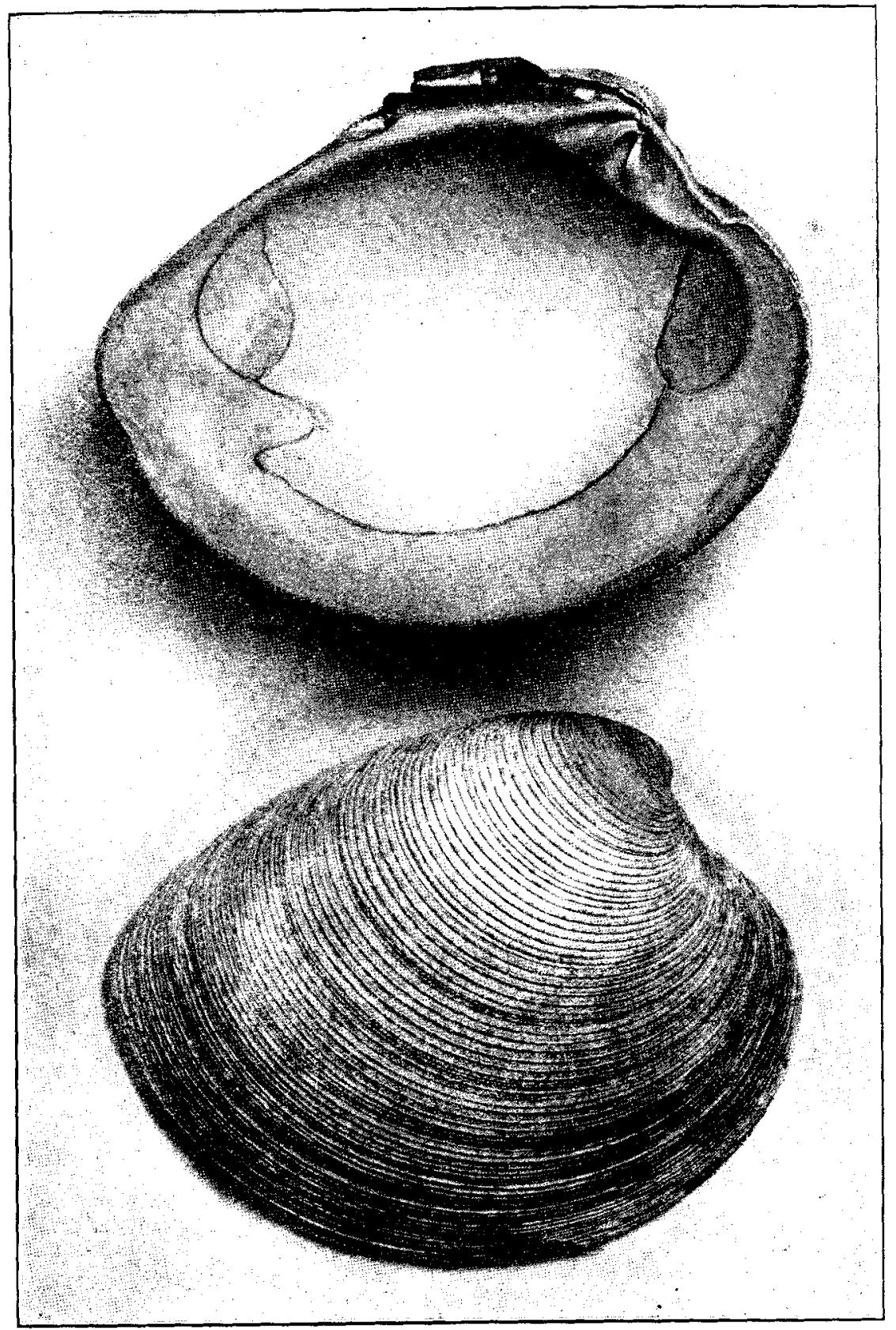

VENUS STIMPSONI, Gould. 
few specimens have come into the possession of conchologists.

Having recently received a shell from Mr. Y. Hirase, of Kyoto (Japan), which $I$ felt sure must be $V$. stimpsoni, as it was clearly a Mercennria, and that is the only Japanese species of the group, I wrote to Mr. E. A. Smith about it. He sent me a copy of Gould's description, but informed me that the Museum did not possess a specimen, and advised me to have the shell compared with the type in the United States Museum. Accordingly I sent it to Dr. P. Bartsch, who has kindly compared it with the type and informs me that it is undoubtedly the $V$. stimpsoni of Gould.

Under these circumstances it seems desirable that the shell should be fgured and more fully described in English, for Gould's description was in Latin only, and ran as follows :-

"Venus (Mercenaria) stimpsoni. T. [i.e. Testa] solida, cinerea, ovato-cordata, satis convexa, laminis erectis concentricis confertis disposite ornata ; umbonibus antemedianis eminentibus, acutis, approximatis; facie dorsali anticâ concavâ; lunulâ profundâ; extremitate anticâ compressa, rotundata; facie dorsali posticâ arcuata, declivi, impressa, nihil nisi striata; extremitate posticâ satis acutâ : cardo validus; cavositas et apophysis ligamentalis aurantiaci; sinu siphonali minime profundo; margine interna simplici. Long. 3.7 ; alt. 3.3 ; lat. 1.7 poll. Inhabits Hakodadi, 6 fathoms."

The Mercenaria group belongs to what should be regarded as the restricted genus Venus, though I have come to that conclusion on different grounds from Dr. Dall, and differ from him in regarding the genus as a much more comprehensive group, for I can see no generic distinction between it and Chione.

'The characters possessed in common by Mercenaria and Chione are: that the external sculpture of the shell is more or less cancellate, the concentric lamellæ predominating, but the radiate riblets show themselves in the crenulated inner margins of the valves ; that the lunule is impressed and the escutcheon is well defined; that all have a thick hinge-plate, bearing three cardinal teeth, but no laterals; and, finally, that the pallial sinus is small, triangular, and pointed.

Mercenaria differs from the typical Chione in always having a rugose area on the nymphal plate of the right valve and on the back of the posterior tooth of the left; such areas being only present in a few species of Chione. The posterior and middle teeth of the right valve are deeply grooved or 
bifid, as also is the median of the left; wherèas in many of the adult Chione the teeth are entire or only feebly grooved.

Specifically Verus stimpsoni may be described as follows:Shell large, solid, triangularly-ovate, more attenuated posteriorly than other species, the postero-dorsal slope being flattened and elongated so as to meet the postero-ventral slope in an angle which approximately subtends the median transverse diameter of the shell. The anterior side is evenly rounded and somewhat compressed. The specimen measures a little over $3 \frac{1}{2}$ inches in length by $2 \frac{3}{8}$ in height; more accurately it is 9 cent. long by $7 \cdot 3$ cent. high across the middle of the shell.

The sculpture consists of numerous low concentric lamellæ which are very close-set on the two sides and near the ventral border of the valves. On the central part of each valve the spaces between the lamellæ are striated concentrically but irregularly, and are also crossed by faint radiating lines. The valves are somewhat compressed, so that the width from centre to centre is less than in $V$. mercenaria and the shell is consequently less ventricose.

The internal characters are like those of $V$. mercenaria, but the rugose areas of the hinge are narrower and less pronounced. The pallial sinus is rather smaller, and the muscular scars rather larger than in the type species. The crenulated inner margin of the valves is very narrow and the crenulations on the lunular margin are faint. Still the margins are not "simple" as stated by Mr. Gould ; possibly his specimen was somewhat worn.

The Mercenaria section of Venus is almost entirely American, $V$. stimpsoni being the only species yet recognized outside American waters, though some Australasian species, such as V. yatei, Gray, and V.alata, Reeve, come very near to it.

There are two species on the east coast of America, $V$. mercenaria, Linn., and $V$. campechiensis, Gmelin (= $V$. mortoni, Conrad). Two also occur on the west coast, viz., V. kennicotti, Dall, and $V$. apodema, Dall, but both are very rare. $V$. stimpsoni is probably most nearly allied to $V$. kennicotti, for Dr. Dall describes this latter species as being yellowish white in colour and closely lamellose over the whole surface; he also says "the rugose area of the hinge is more narrow and delicate than in the Atlantic species, but this area is still further diminished in the Japanese V. stimpsoni (Gould), the only exotic species of the group." 
Mr. Hirase informs me that the speeimen which be sent me came from Yanohe, in the province of Mutsu. This forms the northern end of Hondo, the main island of Japan, and is not far from Hakodate, which is a port near the southern end of the North Island (Ilokkaido). The locality is therefore wear that given by Gould.

\section{EXPIAANATION OF PLATE IV.}

I'enus stimpsoni, nat. size.

XV.-Notes on the Lamellicarn Beetles of the Genus Golofa, with Descriptions of Three new Species. By Ginbert J. Arrow.

(Published by permission of the Trustees of the British Maseum.)

Amongst the most remarkable and fantastic of all the Dynastinæ, if not of all insects, are the large species of the genus Golofa. The number of specics of this genus is now fairly considerable, but they are extremely close and difficult to discriminate, especially when not at their maximum development. Their nomenelature is also in the greatest confusion, the figures and descriptions of the ancient authors being invariably insufficient for exact determination. Most of the originals of these have vanished, but I have carefully examined such types as are available in the endeavour to settle the synonymy so far as possible.

The first-described species, Golofa claviger, Linn., was based upon Martinet's figure in the very rare 'Planches Enluminées' of D'Aubenton, and another in Voet's 'Catalogus Systematicus Coleopterorum,' both of which were quite inaccurately cited by Linnaus, whose own copies of these works (the first a portion only with a titlepage supplied by himself) I have examined in the Linnean Society's Library. 'These figures seem to represent the Mexican G. pizarro of Hope or the closely similar S. American form, while a specimen in the Linnean Collection belongs to the West Indian (St. Vincent) species G. guildinii, Hope. The elytra of this specimen are black instead of red, as described by Linnæus, but as it bears no label at all there is no proof that it has not been added to the collection in later years, like so many others there. As the authors of the two figures mentioned, as well as Linnæus himself, were ignorant of the habitat, it seems impossible to fix the species except 